\title{
Consumers' willingness, behaviors, and attitudes to pay a price premium for local organic foods in Nepal
}

\section{Saugat Khanal}

Faculty of Agriculture, Agriculture and Forestry University, Bharatpur 44200, Chitwan, Nepal

\begin{abstract}
For a few years, the consumers' concerns about environmental and health issues related to organic food products have risen; consequently, the demand for organically grown products has increased and hence the tendency of paying a surplus amount for those products. Keeping this point in view, a study was undertaken in 2020 to investigate the factors affecting consumers' potential willingness to pay premium prices for organic food products in Nepal. The research applied different research methods, in particular, public opinion analysis based on the conducted surveys and the statistical inference method. The data obtained from the survey were analyzed using Pearson's chi-square test which revealed that men were more willing than women to select local organic foods due to their disbelief in conventional foods and their selection was more often than in case of women based on the price of the organic foods. This survey results showed 9.55 percent of respondents would not be willing to pay a premium price, while 91.45 percent would be willing to pay a certain percentage of surplus amounts for organic foods. Results have revealed that factors like personal disposable income, original product price, consumers' lifestyle, self-congruity, Ethics of production, etc. affect the consumer's attitude to paying a premium price. Moreover, health consciousness, environmental protection concerns, and food safety concerns increase the willingness of consumers to purchase organic foods. However, high prices, the paucity of regular supply, insufficient information about the benefits of organic foods, and others have negatively influenced the consumers regarding the purchasing perceptions. In this regard, the research findings can be used to assess the development prospects of the organic foods market, to construct a set of measures increasing the willingness level of the consumers to pay a price premium for local foods, and to take up decisions about the production of organic foods.
\end{abstract}

Keywords-Consumers' willingness, Organic foods, Pearson's chi-square test, Price premium.

\section{INTRODUCTION}

Environmental pollution, emphasizing use of agro-chemicals, expensive production cost, food safety issues, and deteriorating ecosystem health have endorsed the need to shift chemical and external input use agriculture towards intact and plausible organic production (Bhatta et al., 2009). Organic farming is such an agricultural production technique based on respect for natural cycles that preserve the health of soils, ecosystems, and people as well (Koocheki, 2004). The inorganic chemicals used as the chemicals during crop production leave irrefutable effects on the health of the consumers, producers, and the environment (Dehghanian et al., 1998). Inorganic elements not merely poison the soil microorganisms and leave residues on food products, but they also disturb the natural ecosystem of the farm and break apart the food chain (Erfanmanesh and Afyouni, 2007). The global market of organic products is rising as the number of people desiring to have organic foods and pay a premium price is increasing. The worldwide market has experienced exceptionally outstanding growth in organic foods in the United States, Europe, and in other countries, yet market shares endure quite small in developing countries (Piyasiri and Ariyawardana, 2002). Organic farming is flourishing 
rapidly, being practiced globally by 1.8 million producers in 160 countries (Willer et al., 2013). With $66 \%$ of the country's denizens directly involved in farming, Agriculture contribute approximately $28 \%$ of total Gross Domestic Product (GDP) (Khanal and Shrestha, 2019). Many Nepalese farmers plant according to organic agriculture and minimal use of agrochemicals such as pesticides, herbicides, and chemical fertilizers is fairly common among them. Organic farming is a workable solution to avert global hunger by contributing relatively higher yields from low input agriculture in food-deficit regions (Leu, 2004). Looking at the background of Nepal, the organization of the National Organic Agriculture Accreditation Body (NOAAB) and the National Coordination Committee for Organic Agriculture Production and Processing System (NCCOAPPS), encouraging organic agriculture, has made a compassionate environment for organic food production. The investigation has shown that agricultural organic products in Nepal are non-market goods. Such products still have a meager diffusion on the ground that consumers are not always adept to recognize organic products from the conventional ones, because of deprivation in certification procedure and paucity of awareness about these food products.

The momentous contribution of organic foods to human health has increased the willingness of consumers to pay for organic products. The particular business for merchandising organic products has been begun and are earning premium prices in the international and domestic market as well (Paudel, 2017). With time, the market of organic food is gradually expanding, both in terms of follower and producer, in Nepal. With the consistent growing concern among urban Nepalese for organic foods, numerous prospects of organic farming are also surging. People are nowadays better concerned about what they eat and how they are produced or processed. Veeresh(1999) surmises that the concept of a sustainable environment cannot progress together with the development of high technology. Still, and all, in Nepal, there has been no agreeable formulation of plans and policies for producing safer food products. As a consequence, producers have been deprived of the benefits of higher incomes of selling organic products; in addition, the society has been deprived of a healthy diet and a better environment as well. Seeing the verifiable truth that organic products have not been produced assiduously and largely in any part of the country, this study focuses on preparation for the marketing of these products and it investigates consumer's attitude and information towards them. The result of this study could determine the reason for purchasing organic foods by a group of consumers with higher prices and rejecting them by another group. It also would reveal what nature of attributes of consumers would increase consumer's utility and result in buying such foods and what other characteristics would confine consumers' willingness to pay for a price premium.

\subsection{BACKGROUND AND NEED FOR THE STUDY}

Taking into account the significance of this subject in recent years, researches have been carried out on several studies in this field and tried to assess consumer's willingness to pay a premium for organic foods. Wang and Sun (2003), Benett et al. (2009), and krystallis and chryssohoidis (2005)had done similar surveys and analyzed consumers' WTP for organic foods.Brown ch (2003), Buchardi et al. (2005), and Darby et al. (2006) had studied the consumer's attitude and WTP towards local foods. Research has been performed by Misra et al.(1991), Huang et al. (1999), Bocaletti and Nardella (2000) and Tavishi et al. (2006)about consumer's WTP for the pesticide-free product. Such researches encompass a focus of analysis whose priority is given to the values, beliefs, and motivations of the consumers. Many of them have studied how consumers perceive organic products and what are consumers' attitudes towards them. In general, the studies conducted in the South Asian countries showed that the purchase motive of organic products was associated with health and ecological consciousness along with safety and quality issues such as taste, flavor, freshness, and price of the product. In Nepal, Apart from usual concerns with food safety and health security, consumers are also anxious regarding social issues and ecosystem protection. These consumers usually have a more positive attitude concerning local organic foods. The increasing importance of organic food and the ongoing transformation in consumers' lifestyles are invariably persuading studies of such nature. A more psychological approach, emphasizing attitudes, beliefs, and lifestyle may show a consumer of organic foods different from the usual. Considering the above-mentioned facts, it may be confirmed that analyzing farmer's perception, market potential and assessing consumer preferences for organic foods is a current area of investigation in Nepal. So, the above-depicted review recommends that in order to fabricate persuasive policies for boosting production and consumption of organic products, it seems realistic to tap market potential and analyze farmers and consumer's perceptions. 
Agriculture is the solitary biggest sector and propulsive verve of Nepal's economy. The organic food enterprise in Nepal is at an early stage of its development; most of the produce is exported to developed countries. Inorganic farming has resulted in the deterioration of the factor productivity, deforestation, soil loss, and loss of homegrown crop varieties which has raised the concept of sustainability of the production system and thus introduces organic agriculture in many corners of the country notably where assured infrastructure is available. Since organic foods are credence products, consumers may not know whether a product is produced using organic or inorganic methods unless they are told so (Giannakas, 2002). In the present scenario, fruits and vegetables are the most demanded organic food products in the country. In contempt of this growth potential, one of the bottlenecks for organic consumers is a high price for organic foods. Nepal, being a developing country, clearly most of the consumers are not well off. Nevertheless, a large mass of consumers are assembled in and around urban areas of the country, and they could pay for the organic foods provided the quality is assured. Market potentiality is mainly driven by consumer beliefs of the product attributes, which are associated to the product such as quality (Ramesh et al., 2005), price (Roddy et al., 1996) and (Fotopoulos and Krystallis, 2002), price and quality (Boyle and Lathrop, 2009). Smallholder peasants are being forbidden from the export organic supply chains due to several constraints. Thus, the next alternative option for smallholder farmers in the domestic and local market is to sell their produce. On the other side, the organic retailers and wholesalers are not well organized and there are massive differences in their pricing of the products for marketing. Accordingly, awareness and knowledge about organically produced foods are pivotal in consumer purchase decisions.

Analyzing this background and finding the research gap in the domestic marketing of organic foods, this study was performed to contribute to a better understanding of consumer choice of organic products in Nepal. In addition, it determines empirical estimates of consumer willingness to pay a premium for organic foods by emphasizing several factors affecting consumer WTP and impediments for organic products purchase. The knowledge about consumers' willingness to pay a price premium plays a detrimental role in many realms of marketing management such as pricing decisions or new product development. This investigation may help analysts and planners of government policies related to the development of organic food markets.
Consequently, relevant strategies and policies should enhance the prospective organic food markets, forming positive effects for organic farming as a whole.

\subsection{CONCEPTUAL FRAMEWORK OF WTP ANALYSIS}

Consumers always look for food security and are willing to pay a higher price for fresh and organic foods for the reason that they increase their utility level by lessening health risks at the same time. In most cases, the willingness to pay a price premium diminishes as the price premium increases, consistent with the law of demand. Willingness to pay is the tally of money depicting the difference between consumers' surplus before and after adding or enhancing food product attributes (Rodríguez et al., 2007). Organic foods may be reasonably quite expensive than conventional foods. Buyers may be willing to pay a premium for organic foods if they trust them to possess desirable and enticing qualities that conventional foods cannot deliver. The majority of the people favor purchasing organic foods when they believe it to be free from chemical residues and artificial ingredients (Yin et al., 2010), ( Lim et al., 2014), and(Sangkumchaliang and Huang, 2012).Similarly, the intention to buy organic foods decreases with restraint of information and understanding towards those products, with many factors affecting consumers' perceptions and attitudes. As mentioned in the consumer behavior theory, consumers form self-decisions based on an individual's intention to perform a behavior, which is affected by attitudes (Ajzen, 1991). Regarding previous statements, the Nepali organic foods market does not follow in accordance with the usual market rules and consumers usually disbelieve the genuineness of "organic" products presented in the market, perceiving them as "non-market" goods. Women are more hopeful to purchase organic foods, since they are most often the prime food shopper in the family and also conscious of family health and environmental issues (McEachern and McClean, 2002); (Pearson et al., 2011). Married consumers, relative to unmarried have also been found to have more preference for organic products (Dimitri and Dettmann, 2012); (Ward et al., 2012). (Thompson, 1998) and (Onyango et al., 2007) reviewed that young consumers show a higher interest in local organic food. However, older people were more likely to purchase organic foods than the younger ones (Magnusson et al., 2001); (Ghorbani and Hamraz, 2009). 

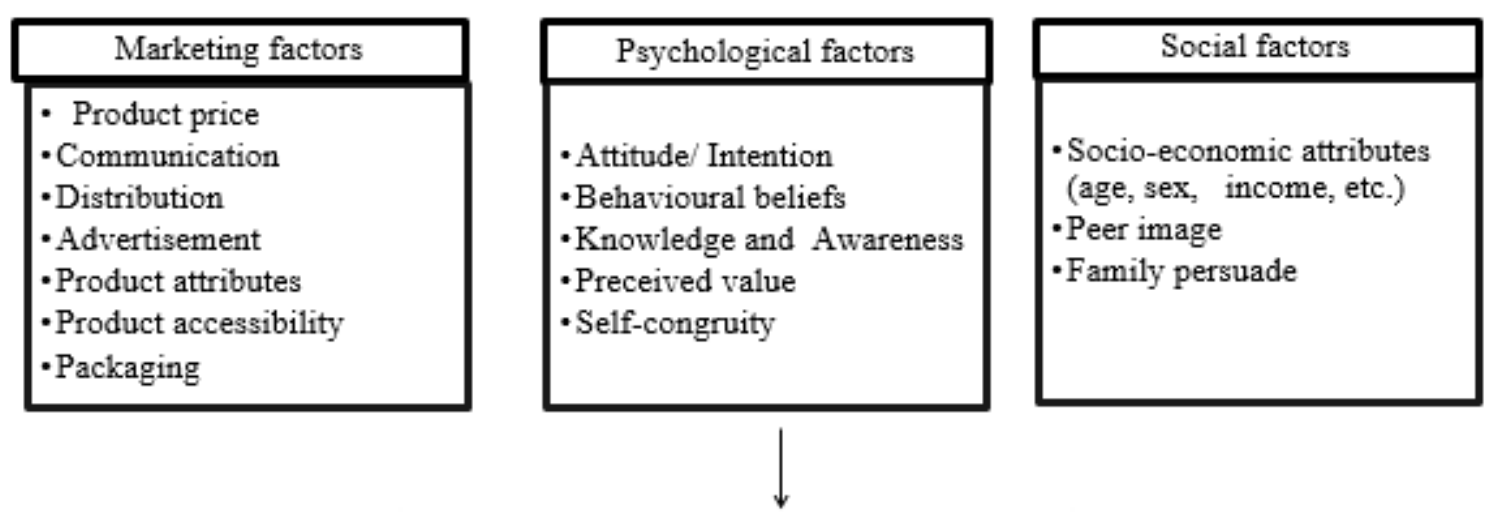

Organic Foods Purchase Decisions

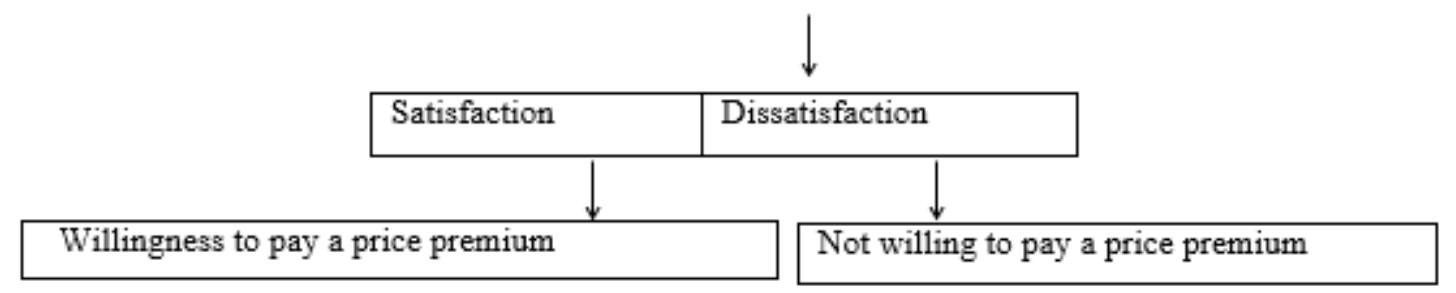

Fig.l Factors affecting the consumer's willingness to pay a price premium

In this study, a simple framework was used to assess consumers' attitudes towards local organic food products, which includes the willingness to pay a price premium according to the satisfaction level. Consumers decide whether to buy a product or not based on three main aspects: Psychological attitude, Marketing factors, and Social aspects. Knowledge and awareness of people are influenced by the type and quality of information made available to the consumers. Advertisement, quality packaging, labeling, and certification have a decisive role in knowledge enrichment. Consumers' willingness to purchase is also determined by exogenous factors like processing, packaging, certification and labeling, product accessibility, and consumers' knowledge and awareness about the products. WTP also relies on the extent to which the organic foods are accessible, distribution level and the communicative behavior of producers with consumers and the advertisement as well. The most important aspect of willingness to pay a price premium is the positive psychological perspectives of the consumers regarding organic foods. Individual norms and self-congruity equally play a deciding role for WTP.

\section{RESEARCH METHODOLOGY}

This research aims at describing the factors affecting consumer's willingness to pay a price premium for local organic foods. A general perception of 'premium' is that it commands a surplus price than the normal price relative to normal foods. A quantitative survey was conducted with a randomly selected sample consisting of 220 respondents who were the consumers of organic products from two major cities of the Federal Republic of Nepal namely Kathmandu and Bhaktapur. Kathmandu is the capital city of Nepal. The study was conducted during January-February, 2020. The method of individual selection was made in two stages; at first, Stratified proportionate random sampling was carried out to identify the consumers' category within Kathmandu and Bhaktapuras the study population is heterogeneous in terms of socio-economic and psychological status. Six types of consumers with dissimilar professions were recognized, based on the presumption that their characters and perceptions affect the willingness to pay a price premium. Then, certain individuals were randomly selected from each category for the individual interview to acquire the necessary information. A total of thirteen traders from Organic Village, Himalayan Organic farm Nepal (HOFN), Asha Puri Organic Farm, Appropriate Alternative Asia (AAA), Herb Nepal Pvt. 
Ltd., Green valley organic farm (GVOF), including staff working in the outlets, were interviewed to understand more about the different products available in the outlets and their present marketing status in the study area.

The research constituted 220 respondents, all were of Nepali origin. Almost one-third of respondents (36.37\%) were from Bhaktapur and the other two-third (63.63\%) from
Kathmandu. Women covered the vast majority of the respondents; 143 (65\% of total). Men, in turn, accounted for 77 respondents (35\%). A total of 140 respondents ( 50 male and 90 female) from Kathmandu and 80 respondents (27 male and 53 female) were selected and interviewed randomly.

Table 1 Demographic distribution of the surveyed area

\begin{tabular}{llll}
\hline City & Male & Female & Together \\
Kathmandu & $50(64.93)$ & $90(62.93)$ & $140(63.63)$ \\
Bhaktapur & $27(35.07)$ & $53(37.07)$ & $80(36.37)$ \\
Total & $77(100)$ & $143(100)$ & $220(100)$
\end{tabular}

Note: Number in the parentheses indicates the percentage

Sources: Survey

The questionnaire was prepared through the pre-testing of each question via individual interviews with the consumers. The research contained measures of general information about organic food products, consumers' purchasing will and attitudes toward organic food products, organic food buyers, non-organic food product buyers, and demographic as well as socio-economic characteristics of the consumers. Data analysis was done by using Statistical Package for Social Sciences (SPSS) and Microsoft Excel (MS Excel), Software Package. The evaluation of differences in the crosstabulation of quality characteristics was carried out employing Pearson's chi-square test ( $\chi 2$ independence tests). In all performed analyses, the maximum permissible type I error $\alpha=0.05$ was adopted, while $\mathrm{p} \leq 0.05$ was assumed statistically significant. The obtained data were then analyzed both quantitatively and qualitatively.

\section{RESULTS AND DISCUSSION}

\subsection{Socio-demographic characteristics}

A total of $220(\mathrm{~N}=220)$ prudent consumers were interviewed through pre-tested structured questions to be acquainted with the information of consumer's attitude towards willingness to pay a price premium for organic foods. The majority of the interviewed population was under the age of 30-70.9\% (over two-thirds of the total surveyed population). Similarly, the population of age 31-35 and 45-60 covered a total of $17.3 \%$ and $10.9 \%$ respectively. Only 4 respondents ( $0.9 \%$ of whole) were above 60 years. The age structure of the sample is shown in Table 2.

Table 2 Age structure of the sample $(N=220)$

\begin{tabular}{ccccc}
\hline Age (years) & Male & Female & Total & \% of whole \\
$15-30$ & 56 & 100 & 156 & 70.9 \\
$31-45$ & 12 & 26 & 38 & 17.3 \\
$45-60$ & 9 & 15 & 24 & 10.9 \\
60 above & - & 2 & 2 & 0.9 \\
Total & 77 & 143 & 220 & 100 \\
\hline
\end{tabular}

Source: Survey 
The majority of the people were educated. Out of the total respondent, 8.63 percent were illiterate, 11.36 percent had primary, 19.09 percent had secondary and 60.9 percent had higher education level. From the study, it was known that the respondents had been living in the study area for many years. About 24.09 percent of people had been living for five years, 30.9 percent for 6-10 years, 19.09 percent for 11-15 years,

Table 3 Socio-demographic characteristics of the study area

\begin{tabular}{|c|c|c|}
\hline Characteristics & Frequency $(\mathrm{N}=220)$ & Percentage $(\%)$ \\
\hline \multicolumn{3}{|l|}{ Gender: } \\
\hline Male & 77 & 35 \\
\hline Female & 143 & 65 \\
\hline \multicolumn{3}{|l|}{ Educational level: } \\
\hline Illiterate & 19 & 8.63 \\
\hline Primary & 25 & 11.36 \\
\hline Secondary & 42 & 19.09 \\
\hline Higher secondary & 134 & 60.9 \\
\hline \multicolumn{3}{|c|}{ Years of respondents been dwelling in the area } \\
\hline $0-5$ years & 53 & 24.09 \\
\hline $6-10$ years & 68 & 30.9 \\
\hline $11-15$ years & 42 & 19.09 \\
\hline $16-20$ years & 26 & 11.81 \\
\hline $20+$ years & 31 & 14.09 \\
\hline \multicolumn{3}{|l|}{ Occupation } \\
\hline Teachers & 35 & 15.9 \\
\hline Officials & 40 & 18.18 \\
\hline Entrepreneur & 38 & 17.27 \\
\hline Health professionals & 37 & 16.82 \\
\hline Worker & 37 & 16.82 \\
\hline Street vendors & 33 & 15 \\
\hline
\end{tabular}

Source: Field Survey, 2020

\subsection{Consumers behavior towards Organic Foods}

The study found that a majority $(96.8 \%)$ of the surveyed respondents had heard about the organic foods. Still, they are often not sure which foods are organic and which are not. The perception and knowledge about organic foods vary depending on the type and nature of consumers. The results
11.81 percent for $16-20$ years and 14.09 percent had been living for more than 20 years. The largest group among those surveyed was made up of officials $(18.18 \%)$ followed by entrepreneurs $(17.27 \%)$, health professionals, and workers both comprising $16.82 \%$, Teachers (15.9\%), and finally street vendors $(15 \%)$. 
natural food, 14 among them (6.36\%) referred food without inorganic elements, 7 consumers $(3.18 \%)$ referred healthy foods and $7.72 \%$ referred others. Through the study, it was known that $94.55 \%$ of the respondents often purchased organic foods. However, $5.45 \%$ of the respondents still have doubts and unclarity regarding organic food products. Most of the people were known about the health benefits of organic foods. $59.09 \%$ of consumers highly trust in the health advantage of organic foods; $33.63 \%$ have normal trust; $1.82 \%$ has negative arguments regarding the health benefits. However, 5.45\% of the respondents were still not familiar with whether organic food is different from other foods in aspects of health benefits or not. There has always been a dispute in the organic market in terms of price fixing of the organic foods. The price varies with seasons, demand, quality, location, marketing policies, and so on. $61.2 \%$ of the respondents supposed the price of organic foods to be significantly higher than the price it has to be. $38.18 \%$ of the consumers were somehow satisfied with the existing prices of organic products in the organic market.

Table 4 Consumers behavior towards Organic Foods

\begin{tabular}{|c|c|c|c|}
\hline S.N & Variables & Frequency & Percentage \\
\hline 1 & Have you ever heard about organic food? & & \\
\hline & Yes & 213 & 96.8 \\
\hline & No & 7 & 3.2 \\
\hline & Total & 220 & 100 \\
\hline 2 & Your main access to information for organic food & & \\
\hline & Word of mouth & 84 & 38.18 \\
\hline & Parent/ relatives & 32 & 14.55 \\
\hline & Health convention & 14 & 6.36 \\
\hline & Internet & 9 & 4.09 \\
\hline & Magazine & 12 & 5.45 \\
\hline & Doctors & 26 & 11.82 \\
\hline & Television & 20 & 9.09 \\
\hline & Nutritional expert & 13 & 5.9 \\
\hline & Others & 10 & 4.55 \\
\hline & Total & 220 & 100 \\
\hline 3 & How do you comprehend the standard of organic food? & & \\
\hline & Food without inorganic elements & 14 & 6.36 \\
\hline & Food free of chemical fertilizers and pesticides & 136 & 61.82 \\
\hline & Natural food & 46 & 20.9 \\
\hline & Healthy food & 7 & 3.18 \\
\hline & Others & 17 & 7.72 \\
\hline & Total & 220 & 100 \\
\hline 4 & Have you ever purchased organic foods? & & \\
\hline & Yes & 202 & 94.55 \\
\hline & No & 12 & 5.45 \\
\hline & Total & 220 & 100 \\
\hline
\end{tabular}




\begin{tabular}{|r|l|c|c|}
\hline 5 & Do you trust in the comparative health advantage of the organic food & 130 & 59.09 \\
\hline & Definitely yes & 74 & 33.63 \\
\hline & Average & 4 & 1.82 \\
\hline & Definitely not & 12 & 5.45 \\
\hline & Not sure & 220 & 100 \\
\hline 6 & Total & & 61.2 \\
\hline & Ye you agree that the organic food price is supposed to be higher? & 136 & 38.8 \\
\hline & No & 84 & 100 \\
\hline
\end{tabular}

Source: survey

Most of the consumers (38.18\%) obtained the information of organic foods through Word of Mouth; some from Parents/ relatives (14.55\%), Health convention (6.36\%), Internet (4.09\%), Magazine (5.45\%), Doctors (11.82\%), Television (9.09\%), Nutritional expert (5.9\%) and others $(4.55 \%)$. Word of mouth is the passing of information and knowledge from one person to others using oral communication. This is the most simple, easy, and more reliable flow of information in the study area. In developed countries, consumers get to know a lot through the internet. Nepal, being a developing country, the consumers are not able to get accessed to the internet in many places. Family and Friends are the most reliable source of information. Slightly very few people declared that they seek information in the Magazine, health conference, and so on.

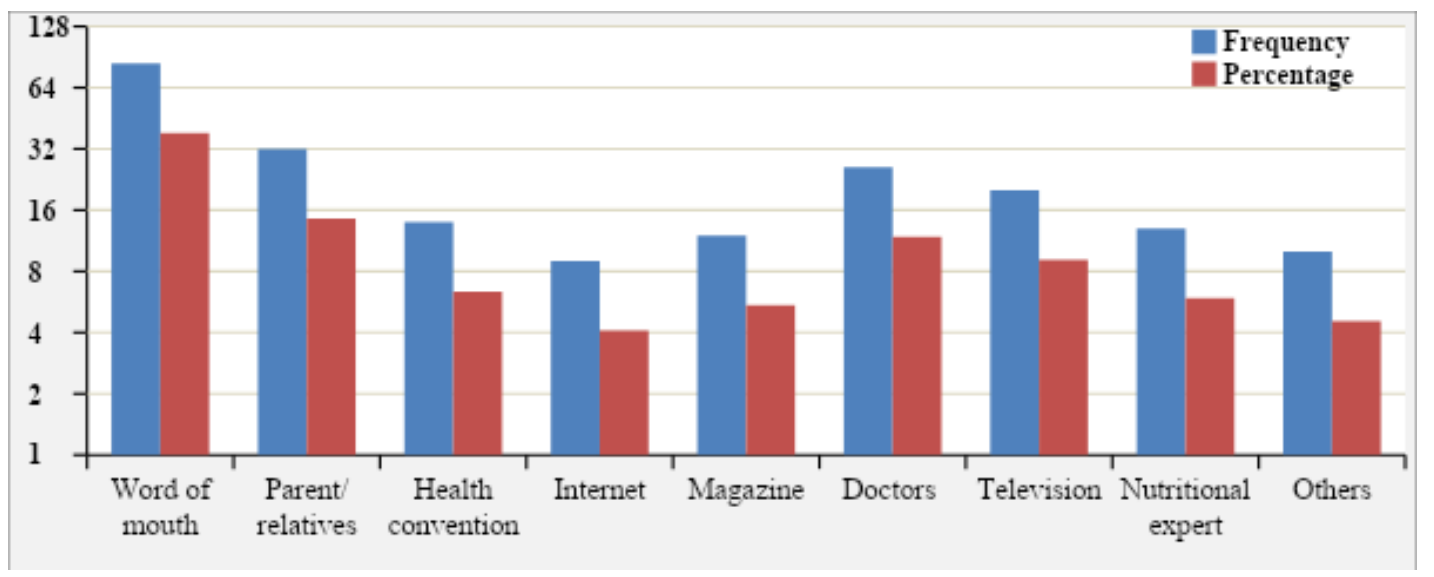

Fig.2 Main accesses to information for organic food

\subsection{Gender differences in preferences for organic foods}

With an objective of checking whether women differed from men in terms of indicating the reasons underlying their preferences of organic foods, the chi-square independence test was performed. We studied whether consumers have any preferences for products that are organically produced. The table below described the obtained research results. 
Table 5 Gender Vs the indication of preferences for organic foods $-\chi 2$ independence tests.

\begin{tabular}{|c|c|c|c|c|c|c|c|c|c|}
\hline \multirow{2}{*}{\multicolumn{2}{|c|}{ Reasons to prefer Organic foods }} & \multicolumn{2}{|c|}{ Male } & \multicolumn{2}{|c|}{ Female } & \multicolumn{2}{|c|}{ Total } & \multirow[b]{2}{*}{$\chi^{2}$} & \multirow[b]{2}{*}{$\mathrm{p}$} \\
\hline & & $\mathrm{n}$ & weightage & $\mathrm{n}$ & weightage & $\mathrm{n}$ & weightage & & \\
\hline \multirow{3}{*}{ Health consciousness } & No & 14 & 19.2 & 19 & 13.2 & 33 & 15 & \multirow{3}{*}{0.94} & \multirow{3}{*}{0.332} \\
\hline & Yes & 63 & 81.8 & 124 & 86.7 & 187 & 85 & & \\
\hline & Total & 77 & 100 & 143 & 100 & 220 & 100 & & \\
\hline \multirow{3}{*}{$\begin{array}{l}\text { Do not trust } \\
\text { conventional foods }\end{array}$} & No & 14 & 18.2 & 52 & 36.36 & 66 & 30 & \multirow{3}{*}{7.87} & \multirow{3}{*}{0.005} \\
\hline & Yes & 63 & 81.8 & 91 & 63.64 & 154 & 70 & & \\
\hline & Total & 77 & 100 & 143 & 100 & 220 & 100 & & \\
\hline \multirow{3}{*}{ Taste better } & No & 15 & 19.5 & 21 & 14.6 & 36 & 16.36 & \multirow{3}{*}{0.84} & \multirow{3}{*}{0.359} \\
\hline & Yes & 62 & 80.5 & 122 & 85.4 & 184 & 83.64 & & \\
\hline & Total & 77 & 100 & 143 & 100 & 220 & 100 & & \\
\hline \multirow{3}{*}{ Nutritional value } & No & 0 & 0 & 0 & 0 & 0 & 0 & \multirow{3}{*}{\multicolumn{2}{|c|}{ no variability }} \\
\hline & Yes & 77 & 100 & 143 & 100 & 220 & 100 & & \\
\hline & Total & 77 & 100 & 143 & 100 & 220 & 100 & & \\
\hline
\end{tabular}

Note: $\mathrm{n}$ —size; $\chi 2$ — chi-square independence test result; $\mathrm{p}$ —significance level.

The study performed employing the chi-square independence test indicated the statistically significant differences between the studied groups in terms of the disbeliefs to conventional foods: $\chi 2(1, \mathrm{~N}=220)=7.87 ; \mathrm{p}<0.050$; - it means that men, more often than women, prefer organic foods due to their disbelief in conventional foods. In terms of the other variables, no statistically significant differences were noticed between the analyzed groups ( $\mathrm{p}>0.050$ ) which means that women did not differ from men regarding the identification of other preferences for choosing local organic foods (i.e., health consciousness, better flavor, and high nutritional value).

\subsection{Gender differences in considering the factors most important in the selection of organic foods}

For the purpose of checking whether women differed from men in terms of specifying the most important factors while choosing local organic foods, the chi-square independence test was employed again in the course of conducted analyses. The table below depicts the obtained research results.

Table 6 Gender vs. the specification of factors most important in the selection of organic foods $-\chi 2$ independence test

\begin{tabular}{|c|c|c|c|c|c|c|c|c|c|}
\hline \multirow{2}{*}{\multicolumn{2}{|c|}{$\begin{array}{l}\text { Attributes of food looked by } \\
\text { the consumers }\end{array}$}} & \multicolumn{2}{|c|}{ Male } & \multicolumn{2}{|c|}{ Female } & \multicolumn{2}{|c|}{ Total } & \multirow[b]{2}{*}{$\chi^{2}$} & \multirow[b]{2}{*}{$\mathrm{P}$} \\
\hline & & $\mathrm{n}$ & Weightage & $\mathrm{n}$ & Weightage & $\mathrm{n}$ & Weightage & & \\
\hline \multirow{3}{*}{ Price } & $\mathrm{No}$ & 3 & 3.89 & 22 & 15.64 & 25 & 11.37 & \multirow{3}{*}{6.56} & \multirow{3}{*}{0.01} \\
\hline & Yes & 74 & 96.11 & 121 & 84.46 & 195 & 88.63 & & \\
\hline & Total & 77 & 100 & 143 & 100 & 220 & 100 & & \\
\hline \multirow{3}{*}{ Nutritive contents } & No & 11 & 14.29 & 24 & 16.78 & 35 & 15.9 & \multirow{3}{*}{0.24} & \multirow{3}{*}{0.629} \\
\hline & Yes & 66 & 85.71 & 119 & 83.22 & 185 & 84.09 & & \\
\hline & Total & 77 & 100 & 143 & 100 & 220 & 100 & & \\
\hline Design of & No & 49 & 63.64 & 96 & 67.13 & 145 & 65.9 & & \\
\hline
\end{tabular}




\begin{tabular}{|c|c|c|c|c|c|c|c|c|c|}
\hline \multirow[t]{2}{*}{ packaging } & Yes & 28 & 36.36 & 47 & 32.87 & 75 & 34.09 & \multirow[t]{2}{*}{0.28} & \multirow[t]{2}{*}{0.602} \\
\hline & Total & 77 & 100 & 143 & 100 & 220 & 100 & & \\
\hline \multirow{3}{*}{ Producer } & No & 67 & 87.01 & 119 & 83.22 & 186 & 84.55 & \multirow{3}{*}{0.56} & \multirow{3}{*}{0.457} \\
\hline & Yes & 10 & 12.9 & 24 & 16.78 & 34 & 15.45 & & \\
\hline & Total & 77 & 100 & 143 & 100 & 220 & 100 & & \\
\hline \multirow{3}{*}{$\begin{array}{l}\text { Availability and } \\
\text { accessibility }\end{array}$} & No & 20 & 25.97 & 38 & 26.58 & 58 & 26.36 & \multirow{3}{*}{0.01} & \multirow{3}{*}{0.92} \\
\hline & Yes & 57 & 74.03 & 105 & 73.42 & 162 & 73.64 & & \\
\hline & Total & 77 & 100 & 143 & 100 & 220 & 100 & & \\
\hline \multirow{3}{*}{ Storage } & No & 25 & 32.46 & 30 & 20.98 & 55 & 25 & \multirow{3}{*}{3.52} & \multirow{3}{*}{0.06} \\
\hline & Yes & 52 & 67.54 & 113 & 79.02 & 165 & 75 & & \\
\hline & Total & 77 & 100 & 143 & 100 & 220 & 100 & & \\
\hline
\end{tabular}

Note: $\mathrm{n}$-size; $\chi 2$ —chi-square independence test result; $\mathrm{p}$ —significance level.

The investigations performed applying the chi-square independence test indicated the statistically significant differences between the studied groups in terms of Product price: $\chi 2(1, \mathrm{~N}=220)=6.558 ; \mathrm{p}<0.050$ which means that men more often than women were influenced by the price factor when purchasing organic foods. In terms of the other variables, no statistically significant differences were noticed between the analyzed groups ( $p>0.050)$ which means that women did not differ from men regarding the identification of other factors guiding their choice of local organic products (i.e., Nutritive contents, Design of packaging, Producer, Availability and Accessibility, and Storage).

\subsection{Willingness to pay a price premium}

The analysis revealed that in the case of product availability, all the consumers are willing to pay surplus prices for organic foods. The price premium is ranging from 5\% - more than $40 \%$ depending upon the products and consumers' willingness to buy. The consumers' survey showed that
$9.55 \%$ of the interviewed consumers $(\mathrm{N}=220)$ are not willing to pay a higher price for organic foods. 10.45 percent of the interviewed consumers are willing to pay up to $5 \%$ price premium compared with conventional foods; 50.9 percent willing to pay $6-10 \%$ premium, 17.27 percent willing to pay $11-20 \%$ premium, 7.72 percent willing to pay $21-40 \%$ premium price and 4.09 percent of the consumers were willing to pay more than $40 \%$ price premium for organic foods. Willingness to pay a premium depends on the utility and the satisfaction the consumers get from the consumption of the organic products. The more they are satisfied, the more desire they have for paying the surplus amount during purchasing. Even if the price increases, the consumers are willing to buy local organic products seeing less risk to their health. The demand for such organic products in Nepal is increasingly growing in the last few years. Also, they are willing to pay a higher amount mainly because of their consciousness towards a healthy life.

Table 7 Willingness to pay a price premium

\begin{tabular}{lll}
\hline Variables & Frequency & \% of whole \\
Not willing to pay & 21 & 9.55 \\
Willingness to pay upto 5\% premium & 23 & 10.45 \\
Willingness to pay 6-10 \% premium & 112 & 50.9 \\
Willingness to pay 11-20 \% premium & 38 & 17.27 \\
Willingness to pay 21-40 \% premium & 17 & 7.72 \\
Willingness to pay above 40\% premium & 9 & 4.09 \\
Total: & 220 & 100 \\
\hline
\end{tabular}




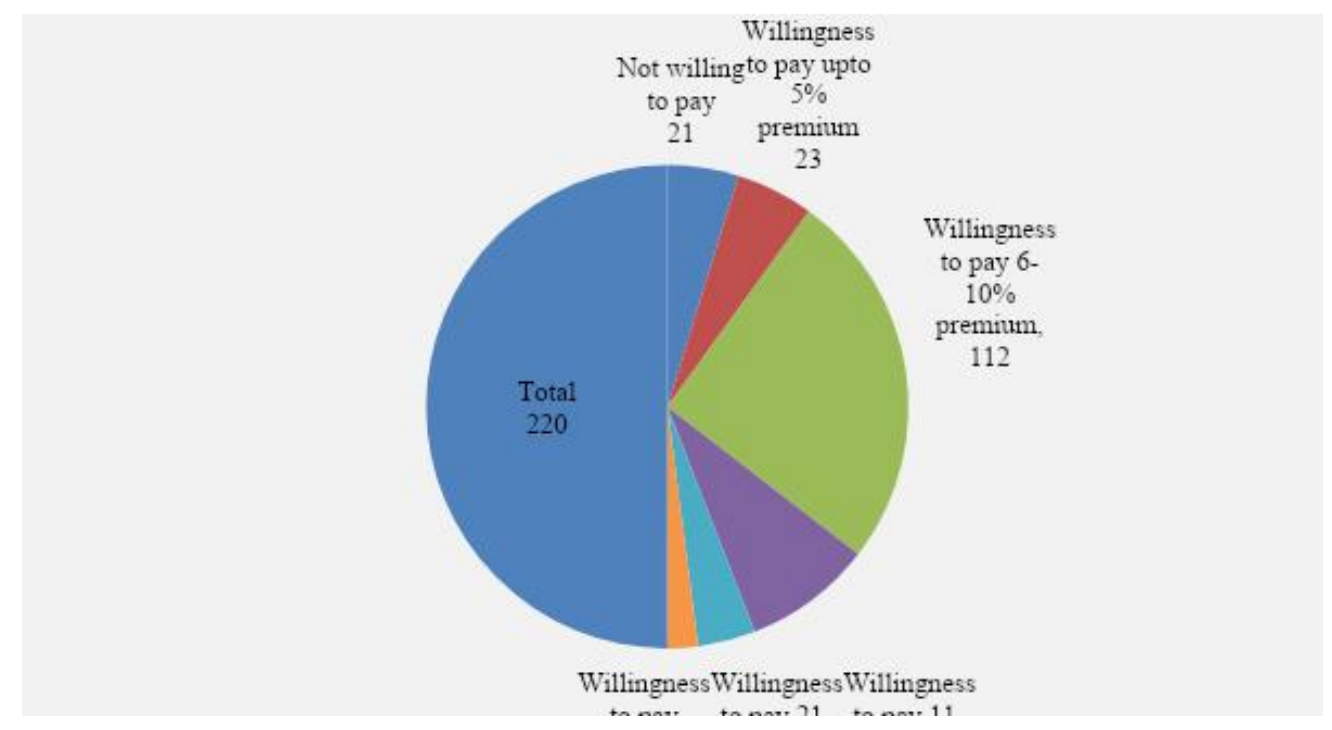

Fig.3 Portion of Willingness to pay a price premium

\subsection{Consumers' knowledge regarding Organic Products}

Consumers in Nepal usually feel unsafe about the food they eat. With increasing technological development, people care more about food safety, nutrition besides food security; meanwhile, food safety is sharpening in a market economy when food risk issues are frequently exposed in the light of the day. As most of the consumers in the study area were educated, they have more knowledge on the advantages of organic foods over conventional foods. A very few (9 consumers i.e. $4.09 \%$ of total) were very poor in knowledge. It is because they were not interested in having organic foods in their diet due to the influence of contemporary society and culture. Similarly, 20 consumers $(9.09 \%)$ had little knowledge. They just knew that organic foods are better than conventional and inorganic foods. But, they were unaware of how such products are more profitable for their life. 50 consumers $(22.73 \%)$ had average knowledge, 96 consumers (43.64\%) had more than average knowledge. 45 consumers (20.45\%) had very high knowledge. They were the ones who also referred other people to purchase organic foods instead of inorganic. They are also more informed about such products. Most of them have understandings about the product. They could distinguish 'what is organic?' and 'what is inorganic?' The consumers having more knowledge show a positive attitude towards premium price and vice-versa.

Table 8 Consumers' knowledge regarding Organic Products

\begin{tabular}{lll}
\hline Consumer's knowledge regarding organic products & Frequency & Percentage \\
Very low & 9 & 4.09 \\
Low & 20 & 9.09 \\
Average & 50 & 22.73 \\
High & 96 & 43.64 \\
Very high & 45 & 20.45 \\
Total & 220 & 100 \\
\hline
\end{tabular}

Source: Survey 


\subsection{Consumer's perception about the price of organic foods with respect to the profession}

Six categories of occupation of the consumers were identified. The officials were most (40) followed by Businessmen (38), health professionals and workers (37 each), Teachers (35), and Street vendors (33). They all were asked to choose whether the price they paid for organic foods is Reasonable, High, Not important, or have no difference from conventional foods. 90 consumers were satisfied with the price they are paying for. They assumed the price of organic foods in the study area to be reasonable. However, 62 consumers supposed the price to be higher than they thought it should be. The comparison of organic products with the inorganic by the consumers might be the determining reason for their perception that the organic products are expensive. The research findings further revealed that despite having an expensive price compared to conventional alternatives, many consumers continue to buy organic foods. This is additionally supported by the research conclusions like consumers who normally purchase organic food were more concerned about food safety than price. 47 consumers expressed that a higher price doesn't matter if the product is really organic. The various studies concluded that the consumers will give second priority to the price of the products and they always look for the quality attributes of the organic foods. Most of the officials' and Teachers choose the price to be reasonable. For the street vendors, due to having less income, they feel the price to be very high to purchase. 21 consumers see no difference in the price of organic foods when compared to other foods; say inorganic or conventional.

Table 9 Consumer's perception about the price of organic foods with respect to the profession

\begin{tabular}{lccccc}
\hline & Reasonable & High & Not important & No difference & Total \\
Teachers & 16 & 9 & 7 & 3 & 35 \\
Officials & 22 & 9 & 5 & 4 & 40 \\
Entrepreneur & 15 & 10 & 9 & 4 & 38 \\
Health professionals & 15 & 10 & 9 & 3 & 37 \\
Worker & 12 & 10 & 12 & 4 & 37 \\
Street vendors & 10 & 14 & 5 & 21 & 33 \\
Total & 90 & 62 & 47 & & 220 \\
\hline
\end{tabular}

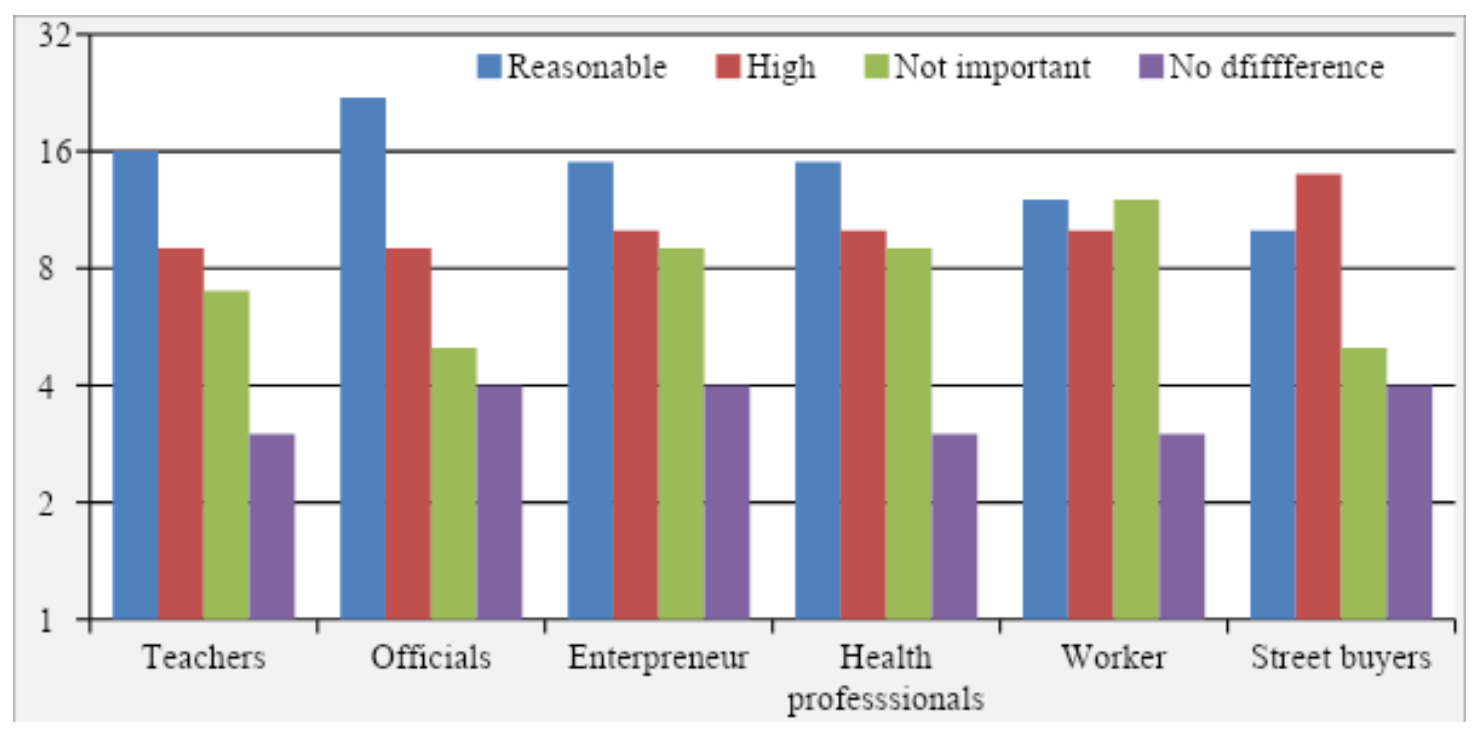

Fig.4 Consumer's perception about the price of organic foods with respect to the profession 


\subsection{Respondent's reason for not paying a price premium for organic foods}

Organic food production has still represented only a small portion of agricultural sales in Nepal and worldwide, but it has been growing rapidly over the last decade. According to the latest agricultural census of farming practices, the area of land certified as organic cultivation in Nepal makes up less than five percent of the country's agricultural land. The cost price of organic products is relatively more than that of conventional food because the organic price tag more closely reflects the true cost of growing healthy and natural food. The non-preference for buying organic foods often include changing perceptions of consumers about just how much healthier they are than non-organics. It means still many consumers are confused in terms of terminologies, premium price, health benefits, and so on. Most of the devotees of organic products buy them in order to avoid exposure to harmful levels of pesticides. Among the surveyed groups of the population, $13.6 \%$ were confused about premium amount; $6.4 \%$ did not see any benefits from consumption of organic foods, $8.27 \%$ did not taste any different from conventional foods; $43.3 \%$ claimed the price to be very high; $12.9 \%$ did not purchase organic products due to insufficient information; $4.12 \%$ due to low quality and $11.23 \%$ were supposed to hold other reasons for not purchasing organic foods.

Table 10 Respondent's reason for not paying a price premium for organic foods

Reasons for not purchasing

Percentage

13.6

Confused (about terminology, premium amount)

Do not see any benefits in organic foods

Do not taste any different from conventional foods

High price

4.12

11.23

Others

100
Confused (about terminology,

premium amount)

Do not see any benefits in organic

foods

Do not taste any different from

conventional foods

High price

Insufficient information about the

products

Low quality

Others

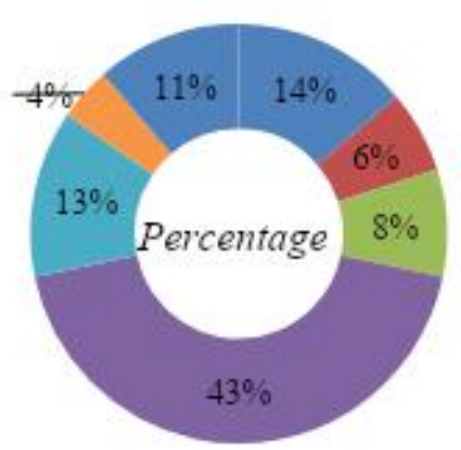

Fig.4 Respondent's reason for not paying a price premium for organic foods
3.9 Overview of the factors affecting consumers' willingness to pay a price premium
Scaling technique, with a seven-point scale $(1,2,3,4,5,6,7$, and 8) was applied to find out the seriousness of the factors influencing consumer's willingness to pay a price premium 
for organic foods. Consumers were asked to choose different categories signifying different strengths of agreement and disagreement. This category was scored and the sum of the scores measures the consumer's attitude towards the price premium. The index of affecting factors was calculated through the following formula;

$$
\mathrm{I}_{\text {prefer }}=\sum\left(\mathrm{Si}^{*} \mathrm{fi}_{\mathrm{f}} / \mathrm{N}\right)
$$

Where $\mathrm{I}_{\text {prefer }}=$ Index of preference

$$
\begin{aligned}
& \sum \text { = summation } \\
& \mathrm{Si}=\text { Scale value } \\
& \mathrm{Fi}=\text { frequency of preference given by consumers } \\
& \mathrm{N}=\text { Total number of consumers }
\end{aligned}
$$

Table 11Ranking of the factors affecting consumers' willingness to pay a price premium

\begin{tabular}{lccccccccccc}
\hline Scale & 7 & 6 & 5 & 4 & 3 & 2 & 1 & Total (N) & I $_{\text {prefer }}$ & Rank \\
Product Price & 62 & 53 & 36 & 24 & 19 & 10 & 16 & 220 & 5.1 & I \\
Convenience in purchasing & 58 & 46 & 33 & 29 & 27 & 19 & 8 & 220 & 4.95 & II \\
Personal disposable income & 40 & 38 & 51 & 33 & 24 & 21 & 13 & 220 & 4.65 & III \\
Consumer's lifestyle & 42 & 31 & 43 & 29 & 33 & 24 & 18 & 220 & 4.44 & IV \\
Self-congruity & 14 & 19 & 25 & 44 & 43 & 45 & 30 & 220 & 3.46 & V \\
Differentiation in product & 3 & 26 & 19 & 23 & 28 & 58 & 63 & 220 & 2.85 & VI \\
Ethics of production & 2 & 5 & 13 & 36 & 48 & 52 & 64 & 220 & 2.57 & VII \\
\hline
\end{tabular}

Source: Own computation

From the study, the most important factors affecting the consumer's willingness to pay a surplus amount was considered to be the original price of the products followed by Convenience in purchasing, Personal disposable income, Consumer's lifestyle, Self-congruity, Differentiation in Product, and finally ranked Ethics of production.

\section{CONCLUSION}

The descriptive result revealed that 91.45 percent of the respondents would be willing to pay a price premium for local organic foods, besides 10.45 percent would be willing to pay upto 5 percent more than the regular prices, 50.9 percent (half of the whole respondents) would be willing to pay 6 to 10 percent of the price premium, 17.27 percent would be willing to pay 11-20 percent while 4.09 percent would be willing to pay more than 40 percent of the price premium. Most of the respondents declared the 'original product price' to be high in their major problem to purchase organic foods. Also, Personal disposable income, Consumer's lifestyle, Convenience in purchasing, etc. are also major factors affecting consumer's intention for not buying the products. Consumers were found to be aware of the harmful effects of inorganic foods. Most of the consumers thought that organic foods are tastier than conventional foods. This shows that there is a potential market for organic foods in Nepal. The conducted analyses showed that men were more likely than women to choose organic foods because of their disbelief in conventional foods and were more often than women guided by the purchase price when buying organic foods. Transparently, health and safety are key motivators for buying organic foods. The main reason for non-purchasers avoiding organic foods is the lack of sufficient information about them. We recommend that future research endeavors include longitudinal studies so that changes in attitudes and purchase behaviors can be analyzed and more fully observed. The conducted research can be employed to improve country policy in the promotion of organic foods and the policy of companies manufacturing products using environmentally friendly technologies that sustain the natural system as well. 


\section{ACKNOWLEDGEMENT}

I am sincerely thankful to Mr. Saurav Khanal; student of Business studies in Tribhuvan University for his expert advice and encouragement throughout the manuscript preparation. I also acknowledge Mrs. Kriti Kiran Dawadi for her kind support during data collection.

\section{REFERENCES}

[1] Bhatta , G. D., Doppler, W., \& KC , K. B. (2009, August)Potentials of organic agriculture in Nepal. The Journal of Agriculture and Environment, 10, 111.DOI: https://doi.org/10.3126/aej.v10i0.2124

[2] Dimitri, C., \& Dettmann, R. L. (2012) Organic food consumers: What do we really know about them? British Food Journal,114(8), 11571183.DOI:https://doi.org/10.1108/00070701211252101

[3] Fotopoulos, C., \& Krystallis, A. (2002) Organic product avoidance: reasons for rejection and potential buyers' identification in a country-wide survey. British Food Journal, 104(3-5), 233-260.DOI: https://doi.org/10.1108/00070700210425697

[4] Ghorbani, M., \& Hamraz , S. (2009) A survey on factors affecting on consumer's potential willingness to pay for organic products in Iran. Trends in Agricultural Economics, 2(1), 10-16.DOI: 10.3923/tae.2009.10.16

[5] Koocheki, A. (2004) Organic farming in Iran. 6th IFOAMAsia Scientific Conference. Yangpyung, Korea: Benign Environment and Safe Food. pp: 7-11

[6] Lim, W. M., Yong, J. L., \& Suryadi, K. (2014)Consumers' perceived value and willingness to purchase organic food.Journal of Global Marketing, 27(5), 298-307.DOI: https://doi.org/10.1080/08911762.2014.931501

[7] Piyasiri, A., \& Ariyawardana, A. (2002)Market potentials and willingness to pay for selected organic vegetables in Kandy. Sri Lankan Journal of Agricultural Economics, 4(1), 107119.DOI: http://dx.doi.org/10.4038/sjae.v4i0.3486

[8] Ajzen, I. (1991) Theory of planned behavior. Organizational Behavior and Human Decision, 50(2), 179-211. DOI:https://doi.org/10.1016/0749-5978(91)90020-T

[9] Benett, R., Costa, L., Cowan C, Holt, G., \& Jones, P. (2009) Consumers' willingness to pay for organic conversion-grade food: evidence from five EU countries. Food pol,34(3), 287294.DOI: 10.1016/j.foodpol.2009.03.001

[10] Bocaletti, S., \& Nardella, M. (2000) Consumer willingness to pay for Pesticide-free Fresh Fruits and Vegetables in Italy. Inter food and Agribus Mng Rev, 3(3), 297-310. DOI:https://doi.org/10.1016/S1096-7508(01)00049-0

[11] Boyle, P. J., \& Lathrop, E. S. (2009) Are consumers' perceptions of price-quality relationships well-calibrated? International Journal of Consumer Studies, 33(1), 58-63. DOI: https://doi.org/10.1111/j.1470-6431.2008.00722.x
[12] Brown ch. (2003). Consumer's preferences for locally produced food: a study in southeast Missouri . Amer J Alter Agri, 18(4), 213-224.

[13] Buchardi, D., Schroder, C., \& Thiele, H. (2005) Willingness to pay for the food of own region: empirical estimates from hypothetical and incentive compatible settings. Selected paper for presentation at the American Agricultural Economics Association Annual Meeting. Rhode island Joly, pp. 24-27.DOI:10.22004/ag.econ.19365

[14] Darby, K., Batte, M., Ernst, S., \& Roe , B. (2006) Willingness to pay for locally produced foods: a customer intercept study of direct market and grocery store shoppers. Selected paper prepared for presentation at the American Agricultural Economis Association Annual meeting, Long Beach, California, pp. 1-31.

[15] Dehghanian , A., koocheki , A., \& Ahari , k. (1998)Ecological economics and economics of organic farming in Iran: Publication of Ferdowsi University of Mahhad.

[16] Erfanmanesh , M., \& Afyouni, M. (2007)Environmental pollution. Esfahan, Iran: Ardakan publication (4th Edition).

[17] Giannakas, K. (2002) Information asymmetries and consumption decisions in organic food product markets. Canadian Journal of Agricultural Economics, 50(2002), 3550. DOI: https://doi.org/10.1111/j.1744-7976.2002.tb00380.x

[18] Huang, C. L., Kamhon, K., \& Tsu, T. F. (1999) Consumer willingness to pay for food safety in Taiwan: a binary ordinal probit model of analysis. J Cons Affairs, 33(1), 76-91. DOI: https://doi.org/10.1111/j.1745-6606.1999.tb00761.x

[19] Khanal, S., \& Shrestha , M. (2019)Agro-tourism: prospects, importance, destinations and challenges in Nepal.Archives of Agriculture and Environmental Science,4(4), 464-471.DOI: https://doi.org/10.26832/24566632.2019.0404013

[20] krystallis , A., \& chryssohoidis , G. (2005) Consumers' willingness to pay for organic food: Factors that affect it and variation per organic product type. Brit Food J,107(5), 320343.DOI: 10.1108/00070700510596901

[21] Leu, A. F. (2004). Organic agriculture can save the world. Well Being Journal,13(2).

[22] Magnusson, M. K., Arvola, A., Hursti, U.-K. K., Åberg, L., \& Sjödén, P.-O. (2001)Attitudes towards organic foods among Swedish consumers. British Food Journal, 103(3), 209227.DOI: 10.1108/00070700110386755

[23] McEachern, M. G.,\& McClean, P. (2002). Organic purchasing motivations and attitudes: are they ethical? International Journal of Consumer Studies, 26(2), 85-92. DOI: https://doi.org/10.1046/j.1470-6431.2002.00199.x

[24] Misra, S., Huang, C., \& Ott, S. (1991). Consumer's willingness to pay for pesticide-free fresh produce. W J Agri Econ, 16, 218-227.

[25] Onyango, B. M., Hallman, W. K., \& Bellows, A. C. (2007) Purchasing organic food in US food systems: a study of 
attitudes and practice. British Food Journal, 109(5), 399411.DOI: 10.1108/00070700710746803

[26] Paudel, S. (2017, May 31). Organic agriculture opportunities in Nepal. My Republica.https://myrepublica.nagariknetwork.com/news/org anic-agricultureopportunities-in-nepal/

[27] Pearson, D., Henryks, J., \& Jones, H. (2011) Organic food: what we know (and do not know) about consumers. Renewable Agriculture and Food Systems, 26(2), 171177.DOI: https://doi.org/10.1017/S1742170510000499

[28] Ramesh, P., Singh, M., \& Rao, A. S. (2005) Organic farming: its relevance to the Indian context. Current Science, 88(4), $33-40$.

[29] Roddy, G., Cowan, C. A., \& Hutchinson, G. (1996)Consumer attitudes and behaviour to organic foods in Ireland. Journal of International Consumer Marketing, 9(2), 4163.DOI:https://doi.org/10.1300/J046v09n02_03

[30] Rodríguez, E., Lacaze, V., \& Lupín , B. (2007) Willingness to pay for organic food in Argentina: evidence from a consumer survey. Contributed Paper prepared for presentation at the 105th EAAE Seminar 'International Marketing and International Trade of Quality Food Products,Bologna, Italy. pp. 187-213

[31] Sangkumchaliang, P., \& Huang, W.-C. (2012) Consumers' perceptions and attitudes of organic food products in northern Thailand. International Food and Agribusiness Management Review, 15(1), 87-102.

[32] Tavishi , C., Nijkamp, P., \& Vindigni , G. (2006)Pesticide risk valuation in empirical economics: a comparative approach. Ecological economics, 56(4), 455-474. DOI: https://doi.org/10.1016/j.ecolecon.2004.06.026

[33] Thompson , G. (1998) Consumer demand for organic foods: what we know and what we need to know. American Journal of Agricultural Economics, 80(5), 1113-1118. DOI: https://doi.org/10.2307/1244214

[34] Veeresh, G. K. (1999) Organic farming ecologically sound and economically sustainable. Plant Horti Tech, 1(3).

[35] Wang, Q., \& Sun, J. (2003)Consumer's preference and Demand for organic food: Evidence from a Vermont survey. Montreal, Canada. American Agricultural Association Annual meeting.DOI: 10.22004/ag.econ.22080

[36] Ward, P. R., Tisdall, L., Henderson, J., Taylor, A. W., Meyer, S. B., \& Coveney, J. (2012) The Social determinants of food purchasing practices: who chooses price-before-health, tastebefore-price or organic foods in Australia? Polish Journal of Food and Nutrition Sciences, 3(4), 461-470.DOI: 10.4236/fns.2012.34066

[37] Willer, H., Lernoud, J., \& Kilcher, L. (2013)The world of organic agriculture: Statistics and emerging trends 2013. Frick, Switzerland. Research Institute of Organic Agriculture (FiBL) \& Bonn: International Federation of Organic Agriculture Movements (IFOAM).
[38] Yin, S., Wu, L., \& Chen, M. (2010) Consumers' Purchase intention of organic food in China. Journal of the Science of Food and Agriculture, 90(8), 1361-1367.DOI: 10.1002/jsfa.3936 